\title{
Determinants of Growth of Private Investment in Dire Dawa City, Ethiopia
}

\author{
Girmay Aklilu \\ College of Business and Economics, Dire Dawa University, Ethiopia
}

\begin{abstract}
Private investment is one of the mainsprings of economic growth. Dire Dawa city has been identified as the low private investment activities in the development and growth of the economy. Thus, the objective of this study is to explain the determinants of private investment in the city. In an attempt to achieve this objective, data was collected through self-administered questionnaire from 171 sample respondents through a systematic sampling technique and analyzed through inferential analysis. Seventeen variables were considered for analysis and the result reveals nine variables, that is, education, marital status, age, personal saving, inflation, public investment, investment incentive, raw materials and land are a statistically significant determinant of private investment of Dire Dawa city. Therefore, if the city has to benefit from the economic rewards of the private investment, it is recommended for all stakeholders to pay more attention to those determinants.
\end{abstract}

Keywords: Administrative factors, factors of production, financial factors, personal factors, private investment.

DOI: $10.7176 /$ JPID/58-01

Publication date: January $31^{\text {st }} 2021$

\section{INTRODUCTION}

Investment is a key variable necessary for economic growth and development of countries. Ouattara (2004) defines investment as a broad and open ended, with a list of specific types which are indicative rather than conclusive. He noted that, the term 'investment' is essentially ambiguous. Moreover, studies done by Antonakis (2008), Seruvatu and Jayaraman (2001), Ndikumana and Verick (2007), Bakare (2011) and Dehn (2000) defined investment in different ways. Among them, some define investment as an activity that involves the acquisition of goods which are intended not to be consumed and others define as the act of obtaining income generating assets either as additions to existing assets or to replace assets that have depreciated. These studies classified the term investment as private investments (investment spent by residential/ nonresidential investors and their objective is mostly for profit and risk diversification and public investment (investment spent by the public or government).

According to Bakare (2011) and Dehn (2000), since private investment is more efficient and less closely associated with corruption, it has a stronger and more positive effect on economic growth than public investment. Similarly, Batistar (2015) supports the idea of private investment playing a greater role than public investment in determining economic growth. The role of the private sector is important in terms of its ability to allocate and employ resources efficiently and its contribution to the quantity of domestic investment. Private investment is not only important for job and employment creation, but it also has a role in the acceleration of both infrastructure and social services. According to them, in recent years, emphasis has been given for the development of the private sector in developing countries to help boost economic growth and reduce poverty.

According to the study conducted by Frimpong and Marbuah (2010), United Nations (2002), and World Bank (2004) report, private investment have an important role in job creation, growth expansion and poverty reduction. Meaning that the mobilization of private investment is essential for the development of a country and this can contribute directly to economic growth. On the contrary, where the growth of private investment is low, the productive capacity of the economy fails to increase and it results in lower rates of growth and job creation, and fewer opportunities for the poor to improve their livelihoods.

Furthermore, according to Access Capital Investment Assessment Report (2011/2012), the ratio of private investment to GDP in Ethiopia has been averaged between 5.8 and 10\%. This ratio is below the levels being practiced in successful nations' economies, which is required to support economic growth needed for employment creation and poverty reduction.

Due to the fact that private investment is below expectation, the government of the Federal Democratic Republic of Ethiopia has recognized and paid due attention to the promotion and development of private investment which includes working a lot to attract private investors for investment in different sectors of the economy. Those investment incentive packages are implemented in all cities of the country, including Dire Dawa city. Similarly, based on the Ethiopian Investment Proclamation, Dire Dawa city investment office was established and has been legally performed since 1986 E.C. After four years of preparation, the office had begun the activities of legally registering and administering private investment projects and related activities.

In spite of different investment incentives given by the government for the private sector, Dire Dawa city has been identified as the low private investment activities in the development and growth of the economy. The 
number of evidences shows that private investment in anywhere depends on a number of variables which significantly affects the growth of the sector. So, identifying and monitoring those variables is a precondition for the growth and development of the private investment sector and it can be seen as the most certain way of enhancing private investment. But, the absence of research on the area, that is, Dire Dawa city has long been facing serious problem in minimizing private investment hassles so that the city can be benefited out of the actions. The purpose of this study is therefore, to explore and explain determinants that affect private investment in the city and thereby contribute its level best in this scenario.

Therefore, in order to achieve the objective of this study through thorough review of literatures and pilot survey, 17 variables were hypothesized as determining variables. The result of the analysis reveals 9 variables, that is, education, marital status, age, personal saving, inflation, public investment, investment incentive, raw materials and land, a statistically significant determinant of private investment of Dire Dawa city.

\section{LITERATURE REVIEW}

\section{Theoretical literatures}

Ever since Keynes (1936) who was one of the pioneers of investment theories carried out an analysis which showed the ex-post equality between savings and investment, the offshoots of his submission later brought about some other investment theories like accelerator theory of investment, neoclassical, flexible, Tobin's Q and neo liberal theory. Hence, these theories were theoretically identified to modeling investment in the existing investment literature.

The first model was the simple accelerator theory of investment by Clark (1917) which states investment as a linear function of output change in the economy. This theory has not given emphasis to the cost of capital goods, expectation and profit in its model. In addition, the model also assumes that the ratio of desired capital to output is constant, but in reality it varies with a variation in the cost of capital and technology.

Flexible accelerator model was designed by Hall and Jorgenson (1969). It is the partial adjustment model of investment based on the optimal accumulation of the capital. This means, the larger gap between the existing and the desired capital stock reveals the more investment rates. According to this model, output, internal funds, cost of external financing and other variables are treated as the determinants of desired capital stock which are ignored by the simple accelerator model. However, a particular drawback of this model is that it does not rationalize the rate of investment or movement toward the optimal capital stock.

In addition to flexible accelerator, neo classical model was developed by Hall and Jorgenson (1969). It is similar to the flexible model but desired capital stock is proportional to output and the user cost of capital which in turn depends on the price of capital goods, the real rate of interest, the rate of depreciation and the tax structure. This model was criticized for its limitation in estimating investment function, that is, lack of readily available methods of measuring capital stock and returns to capital for developing countries.

Another theory of investment which was developed by Tobin (1969) was known as the Tobin's q theory of investment. He argues that firms' investment level depends on the ratio of the present value of installed capital to the replacement cost of capital (the Q ratio)

The main criticism of $\mathrm{q}$ theory is that its use tends to be chosen on an informal basis rather than on optimization theory. In addition, the model is confronted with such problems as measuring marginal rather than average user cost of capital, accounting for intangibles that affect market value and incorporating tax factors.

The last investment theory is the neoliberal view of investment which was developed by McKinnon (1973) and Shaw (1973). This view gives emphasis to the importance of financial deepening and high interest rates in stimulating economic growth. According to them, if economy was free up from repressive conditions, this would induce savings, investment and economic growth. Finally, the same criticisms of neo classical also applied to this model.

\section{Empirical literatures}

By focusing on different variables that determine private investment, many researchers have studied private investment from different perspectives. The researcher provides an overview of empirical studies on private investment and this is presented as the following.

Haroon and Naser (2011) using consumer price index to refer to inflation rate, they examine the determinants of investment in Pakistan. They found that, private investment is a function of inflation rate, indirect taxes, subsidies given by the government, discount rate, gross domestic product, domestic savings, government development expenditures, amount of debt servicing, and past private investment (investment experience).

Ang (2010) carried out a study on the availability of financial resources and a greater level of aggregate output has a strong positive impact on private investment, while macroeconomic uncertainty has a negative influence. Both foreign direct and public investments have a complementary effect on private investment.

Matwanga (2007), found a positive influence of savings, GDP growth and public investment on the behavior of private investors in Kenya. Similarly, Kariuki (2003) found that public investment positively affects private 
investment while studying the determinants of gross fixed capital formation in Kenya. Abhijeet and Dinesh (2010) found that investment experience is significantly determining both the investor behavior and investment decision. The study concludes that increase in the experience will be helpful to the investor.

Frimpong and Marbuah (2010) conducted an empirical assessment of factors that have stimulated private sector investment in Ghana. Using the co-integration and error correction techniques within an ARDL framework, their results suggest that private investment is determined by public investment, inflation, real interest rate, openness, real exchange rate and a regime of constitutional rule.

Raza et. al.(2013) carried out a study on the relationship and impact of demographic variables on investment decisions in Pakistan. The findings of their study were men and youngsters are risk takers as compared to women and the older generation. Moreover, Kabra et al. (2010) examine the factors that influence investment risk tolerance and decision making process. This study concludes that the investors' age and gender mainly influence the risk taking capacity of the investors. Knight and Ding (2009) found that private investment has been increased due to an increase in rate of return on capital savings, lower inflation rate, interest rate, expansion in education leading to expansion in investment with high effectiveness, and a rapid rise in economic growth results in corresponding growth in investment.

Ang (2010) conducted a study on the determinants of private investment in Malaysia in 2010 using OLS analysis and ECM methods found that both foreign direct investment and public investment have a positive effect on private investment. A greater level of aggregate output raises the level of private investment.

Gilliam and Grable (2010) analyzed the impact of age and gender in the investment decision. The author observed gender based estimation bias which relates to household decisions that involves financial risk. The author concludes that older investors were more likely to underestimate their financial risk tolerance because of past experience. Wahid et al. (2008) using Panel data of five South Asia countries over the period 1973-2012, found the existence of low positive correlation between savings and investment in three selected Asian countries. Heena (2015) examined the relationship between demographic variables and personality traits on investors' attitude towards risk that may have an impact on the investment growth. The author found that there is a positive relationship between education and investment decisions. Herrmann (2007) using multiple specifications and leveraging multiple risk/return measures, provided the roles of gender in investment preferences. The study concludes the significant effect of gender in investment.

Adugna (2013) conducted a study on the determinants of private investment in Ethiopia using the ECM model. His findings revealed that public investment, real GDP per capita, inflation, international trade, corporate tax, and external debt have a positive relationship while interest rate and exchange rate have negative relationships with private investments. Moreover, Bader and Malawi (2010) study the impact of interest rate on investment using a co-integration analysis method, declare that the real interest rate has a negative impact on investment, while the income level has a positive impact on private investment.

Ahangari and Saki (2012) studied the determinants of private investment in Iran. They found that private investment is a function of instability index, government investment, income from oil and gas exports, value added of industry, and banks' credits.

Bakare (2011), using the ECM model, studied the determinants of private domestic investment in Nigeria. He found that public investment is competitive (not complementary) for private investment. A depreciation of the exchange rate has a negative influence on private investment because it makes imports of capital goods and raw materials more costly for investors. An increase in corruption index and political instability prevent investment to grow. A rise in saving and an improvement in infrastructure, stimulate private investment.

Abhijeet and Dinesh (2010) found that investment experience is significantly determining both the investor behavior and investment decision. The study concludes that increase in the experience will be helpful to the investor. Sajid and Sarfraz (2008) investigate the causal relationship between investment and exchange rate on saving and economic growth in Pakistan. The study used co-integration technique and vector error correction model to examine causality between investment and exchange rate. Their result showed that there is long-run as well as a short run equilibrium relationship between them.

Jordan et al. (2010) studied the impact of interest rate on investment using a co-integration analysis method, declared that the real interest rate has a negative impact on investment, while the income level has a positive impact on private investment.

\section{Conceptual framework}

In order to make the study conceptualized and easily understandable, it was framed and hypothesized based on the factors reviewed from literatures in the following way.

The conceptual framework (Figure 1) reveals the relationship between the personal factors (age, gender, education, marital status and investment experience), financial factors (private saving, credit facility, inflation, interest rate given for saving and interest rate charged on loan), administrative factors (tax administration, investment incentives, good governance and public investment), factors of production (land, labor and raw 
material) and the private investment. In addition, for the smooth running of the study, the null hypotheses were developed using each of the 17 variables depicted on the conceptual framework.

Independent variables

Personal factor
Age
Gender
Education
Investment experience
Marital Status

Financial Factors
Private Savings
Credit Facility
Interest Rate on Loan
Interest Rate for Saving
Inflation

Administrative Factors
Tax Administration
Investment Incentive
Good governance
Public investment

Factors of Production
Raw Material
Land
Labor

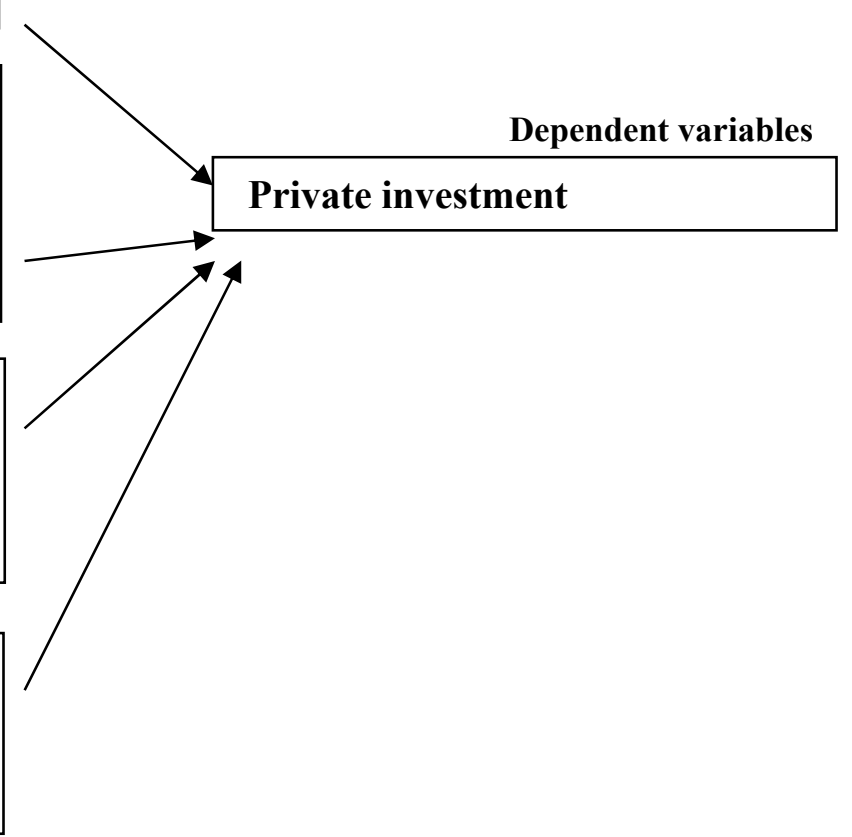

Figure 1. Conceptual framework.

Source: combined from Literatures.

\section{Hypothesis}

The following hypotheses were developed based on the contradictory results of variables in different literatures. As the aforementioned, each of the four predicting variables are represented by their own sub variables. The hypotheses are written in the null form.

(1) Personal factors are not statistically significant determinants of private investment of the city

(2) Financial factors are not statistically significant determinants of private investment of the city

(3) Administrative factors are not statistically significant determinants of private investment of the city

(4) Factors of production are not statistically significant determinants of private investment of the city

\section{Types and sources of data}

Primary data used were sourced from the investment office and the private investors through the use of selfadministered questionnaire. Among the total number of 306 private investment projects, 171 projects were selected through a systematic sampling technique.

\section{Model specifications}

Due to the nature of the dependent variable (being dichotomous), logistic regression was developed which allows the establishment of a relationship between a binary outcome variable (the dependent variable) and a group of predictor variables.

$\operatorname{logit}(\mathrm{p})=\log (\mathrm{p} /(1-\mathrm{p}))=\beta 0+\beta 1 \times \mathrm{x} 1+\ldots+\beta \mathrm{k} \times \mathrm{xk}$

The parameters in the logistic regression model can be estimated by maximum likelihood.

For this study, the overall logistic function equation which includes the personal, financial, administrative factors and factors of production variables are:

Predicted logit of Competition $=\beta 0+\beta 1 \times$ Age $+\beta 2 \times$ Gender $+\beta 3 \times$ Marital $+\beta 4 \times$ Education $+\beta 5 \times$ experience $+\beta 6 \times$ Private saving $+\beta 7 \times$ Inflation $+\beta 8 \times$ Credit facility $+\beta 9 \times$ Loan Interest rate $+\beta 10 \times$ Saving $\&$ Interest rate $+\beta 11 \times$ Public-investment $+\beta 12 \times$ Good-governance $+\beta 13 \times$ Taxadmin $+\beta 14 \times$ Investment 
incentive $+\beta 15 \times$ Labor $+\beta 16 \times$ Land $+\beta 17 \times$ Material

\section{Regression Tests}

Before conducting regression tests, evaluations of the logistic regression which includes checking of the model's assumptions, overall model evaluation, goodness of fit statistics, validation of predicted probabilities and statistical tests of individual predictors were done.

\section{RESULTS AND DISCUSSION}

Since conceptual framework was developed for the smooth running of the study, the analysis was done in four separate ways which is in accordance with this framework. So, the analysis which shows the association between these four factors and the private investment growth level separately is presented subsequently.

Association between the personal factors and the private investment growth level

This test helps to assess the fit of a logistic model against actual outcome.

Table 1. Hosmer and Lemeshow test for personal factors and the private investment growth level.

\begin{tabular}{cccc}
\hline Step & Chi-square & Df & Sig. \\
\hline 1 & 8.879 & 8 & 0.353 \\
\hline
\end{tabular}

Source: Questionnaire and SPSS 20 result.

Table 2. Model summary of personal factors and the private investment growth level.

\begin{tabular}{cccc}
\hline Step & $\mathbf{- 2}$ Log likelihood & Cox \& Snell R Square & Nagelkerke R Square \\
\hline 1 & 101.363 & 0.530 & 0.716 \\
\hline Source: Questionnaire and SPSS 20 result. & &
\end{tabular}

The result shown in Table 1, supports the model being worthwhile. For the Hosmer and Lemeshow test, poor model fit is indicated by a significance value less than 0.05 . To support the study model, the value must be greater than 0.05 . In this test the chi-square value for Hosmer and Lemeshow test is 8.879 with a significance level of 0.353 . This value is larger than 0.05 , therefore indicating support for the model.

Table 2 show another piece of information about the usefulness of the model. The Cox \& Snell R Square and Nagelkerke R Square values provide an indication of the amount of variation in the dependent variable explained by the model (from the minimum level 0 to a maximum of approximately 1 ). In this case, the two values are 0.530 and 0.716 . The model as a whole explained 53.1\% (Cox \& Snell R Square) and 71.6\% (Nagelkerke R Square) of the variance competition perception (Dependent Variable).

From Table 1, the variables age, education and marital status are found to be statistically significant determinants of private investment. According to Geetha and Ramesh (2011), Jain and Mandot (2012) and Sadiq, and Ishaq, (2014), investment performance or decision making process of private investor is based on his/her age. In addition, young investors may face more difficulty in accurately assessing about their work performance as compared to older/matured ones. Matured people gain investment knowledge and experience, and make better investment choices which directly results in the growth of investment.

Table 3. Regression result of personal factors and the private investment.

\begin{tabular}{llllcll}
\hline Predictor variable & B & S.E. & Wald & Df & Sig. & Exp(B) \\
\hline Gender (Female) & 1.165 & 0.772 & 0.046 & 1 & 0.831 & 1.008 \\
Age & - & & 25.552 & 2 & 0.000 & - \\
Age (25-54) & 4.198 & 0.856 & 24.031 & 1 & 0.001 & 13.567 \\
Age (55-64) & 1.788 & 0.683 & 0.683 & 1 & 0.343 & 3.532 \\
Experience & 0.020 & 0.078 & 0.067 & 1 & 0.796 & 1.420 \\
Education & - & & 10.742 & 4 & 0.000 & - \\
Education (Primary S.) & 2.458 & 0.732 & 22.340 & 1 & 0.000 & 16.253 \\
Education (Secondary S.) & 2.749 & 2.118 & 0.685 & 1 & 0.194 & 4.926 \\
Education (Prep or TVT) & 2.354 & 0.836 & 0.922 & 1 & 0.105 & 4.526 \\
Education (Higher Inst) & 0.688 & 0.900 & 0.584 & 1 & 0.445 & 2.990 \\
Marital (Married) & 1.885 & 0.619 & 9.282 & 1 & 0.002 & 6.590 \\
Constant & 1.607 & 1.248 & 0.620 & 1 & 0.520 & 1.610 \\
\hline SOInt Qu & & & & & &
\end{tabular}

Source: Questionnaire and SPSS 20

result. 
Table 4. Hosmer and Lemeshow test for financial factors and the private investment growth level.

\begin{tabular}{cccccc}
\hline Step & Chi-square & df & Sig. \\
\hline 1 & & 4.943 & 7 & 0.667 & \\
\hline
\end{tabular}

Source: Questionnaire and SPSS 20 result.

As shown in Table 3, marriage has a positive effect on private investment performance. This finding goes in line with the study conducted by Geetha and Ramesh (2011), Grable and Joo (2000) and Jamshidinavid et al. (2012). This is due to the shared responsibilities with their partners; they end up contributing more to the economy in many more different ways than when they were single. Having lower level of education has negative effect on the growth of private investment in the city. According to Geetha and Ramesh (2011), Jain and Mandot (2012), Jamshidinavid et. al.(2012), Kenzu (2012), Record and Davies (2007), and Doppelhofer and Miller (2004), investor's educational qualification affects the ability to choose between different investment type and overall it affects the investment decision. This is to mean that an increase in educational level of investors may lead to an increase of better decisions to be made. Other variables such as investment experience and gender have insignificant effect on private investment. Following this result, the study rejects the null hypotheses that state age, education and marital status are not a statistically significant determinant of private investment in Dire Dawa.

\section{Association between the financial factors and the private investment growth level}

The result shown in Table 4, supports the model being worthwhile. In this test, the chi-square value for Hosmer and Lemeshow test is 4.943 with a significance level of 0.667 . This value is larger than 0.05 , therefore indicating support for the model.

The Cox \& Snell R Square and Nagelkerke R Square values provide an indication of the amount of variation in the dependent variable explained by the model (from the minimum level 0 to a maximum of approximately 1 ). Table 5. Model summary of financial factors and the private investment growth level.

\begin{tabular}{cccc}
\hline Step & $\mathbf{- 2}$ Log likelihood & Cox \& Snell R Square & Nagelkerke R Square \\
\hline 1 & 138.079 & 0.418 & 0.565 \\
\hline
\end{tabular}

Source: Questionnaire and SPSS 20 result.

Table 6. Regression result of financial factors and the private investment.

\begin{tabular}{lcccccc}
\hline Predictor variable & B & S.E. & Wald & Df & Sig. & $\operatorname{Exp(B)~}$ \\
\hline Inflation (Yes) & -1.799 & 0.691 & 6.395 & 1 & 0.005 & 0.736 \\
PSaving (No) & 3.169 & 0.633 & 12.042 & 1 & 0.002 & 8.776 \\
Loan_InterestR (No) & -0.351 & 0.632 & 0.309 & 1 & 0.579 & 0.104 \\
Saving_InterestR (Yes) & 0.566 & 0.675 & 0.703 & 1 & 0.402 & 3.568 \\
Credit_Facility (Yes) & 0.032 & 0.808 & 0.002 & 1 & 0.969 & 1.032 \\
Constant & .463 & 0.771 & 0.213 & 1 & 0.061 & 5.085 \\
\hline
\end{tabular}

Source: Questionnaire and SPSS 20 result.

Table 7. Hosmer and Lemeshow test for administrative factors and the private investment growth level.

\begin{tabular}{ccccc}
\hline Step & Chi-square & df & Sig. \\
\hline & 1 & 0.904 & 6 & 0.989 \\
\hline
\end{tabular}

Source: Questionnaire and SPSS 20 result.

From Table 5, the two values are 0.418 and 0.565 , the model as a whole explained $41.8 \%$ (Cox \& Snell R Square) and 56.5\% (Nagelkerke R Square) of the variance competition perception (Dependent Variable).

From Table 6, the variables inflation and personal saving are found to be statistically significant determinants of the extent of private investment in the city. The negative effect of inflation on the growth of private investment was confirmed by Jongwanich and Kohpaiboon (2008) and Knight and Ding (2009), high rates of inflation adversely affect private investment activity by increasing the riskiness of longer-term investment projects. The increasing rate of inflation in the city was observed by restraining investors from diversifying their business who are willing for it, which results in the existence of few projects and low competition. On the other hand, according to Verma (2009) and Matwanga (2007), private saving is the source of growth and that higher saving rate would foster economic growth by serving as initial capital for the expansion of existing business or establishing of the new ones. In the case of Dire Dawa, the absence of personal saving contribution for the investment can be a prediction to the low competition of the private sector. If the personal saving behavior of individuals improved, new investment decision would be made which may result in the improved number of private projects and the low concentration would have been changed to high. In short, while an increase in personal saving caused a positive effect for the growth of private investment, an increasing inflation rate negatively determine the growth of private investment. Other variables such as credit facility and interest rate that is, given for saving and 
charged on loan have no significant effect on the growth of private investment. Following this result, the study rejects the null hypotheses that state personal saving and inflation are not a statistically significant determinant of private investment in Dire Dawa.

Association between the administrative factors and the private investment growth level

The result shown in Table 7 supports the model being worthwhile. In this test, the chi-square value for Hosmer and Lemeshow test is 0.904 with a significance level of 0.989 . This value is larger than 0.05 , therefore indicating support for the model.

The Cox \& Snell R Square and Nagelkerke R Square values provide an indication of the amount of variation in the dependent variable explained by the model (from the minimum level 0 to a maximum of approximately 1 ). Table 8. Model summary of administrative factors and the private investment growth level.

\begin{tabular}{lcccccc}
\hline Step & -2 Log likelihood & \multicolumn{1}{c}{ Cox \& Snell R Square } & \multicolumn{2}{c}{ Nagelkerke R Square } \\
\hline 100.200 & \multicolumn{2}{c}{0.534} & & 0.721 \\
\hline Source: Questionnaire and SPSS 20 result. & & & & & \\
From Table 8, the two values are 0.534 and 0.821, the model as a whole explained 53.4\% (Cox \& Snell R \\
Square) and 72.1\% (Nagelkerke R Square) of the variance competition perception (Dependent Variable). \\
Table 9. Regression result of administrative factors and the private investment. \\
Predictor variable & B & S.E. & Wald & Df & Sig. & Exp(B) \\
\hline Good governance (Good) & 0.285 & 0.555 & .263 & 1 & 0.608 & 1.752 \\
Public investment (Poor) & 4.238 & 0.621 & 46.648 & 1 & 0.000 & 25.281 \\
Investment Incentive (poor) & 2.329 & 0.586 & 5.806 & 1 & 0.021 & 6.68 \\
Tax administration (Good) & 0.791 & 0.602 & 0.723 & 1 & 0.189 & 2.205 \\
Constant & 0.548 & 0.829 & 0.320 & 1 & 0.100 & 2.029 \\
\hline
\end{tabular}

Source: Questionnaire and SPSS 20 result.

Table 10. Hosmer and Lemeshow test for factors of production and the private investment growth level.

\begin{tabular}{cccc}
\hline Step & Chi-square & df & Sig. \\
\hline 1 & 1.033 & 4 & 0.905 \\
\hline
\end{tabular}

Source: Questionnaire and SPSS 20 result.

From Table 9, the variables public investment and investment incentives have a significant effect on private investment. Different studies reveal that the more the government expenditure on infrastructure and the more investment incentives prepared by the government, the more private investment to be encouraged (Abbott and Jones, 2011; Alesina et. al., 2008; Arpaia and Turini,2008; Bakare, 2011; Benos, 2009; Ghosh and Gregorious, 2008; Kenzu, 2012; Lamartina and Zaghini, 2008; Szarowska, 2012; Teklebirhan and Sahlu 2014). Contrary to this, the poor level of public investment and investment incentive practice in the city was negatively affecting the growth of the private sector investment in the city. Such public investments and investment incentives obviously create favorable environment for the private investment. Studies also point to higher levels of investment, greater productivity and faster growth of firms that have better access to infrastructure and received appropriate incentives. Other variables such as tax administration and good governance have no significant effect on the growth of private investment. Following this result, the study rejects the null hypotheses that state public investment and investment incentives are not a statistically significant determinant of private investment in Dire Dawa.

\section{Association between the factors of production and the private investment growth level}

The result shown in Table 10 supports the model being worthwhile. In this test, the chi-square value for Hosmer and Lemeshow test is 1.033 with a significance level of 0.905 . This value is larger than 0.05 ; therefore, indicating support for the model.

Table 11. Model summary of factors of production and the private investment growth level.

\begin{tabular}{ccccc}
\hline Step & -2 Log likelihood & Cox \& Snell R Square & Nagelkerke R Square \\
\hline 1 & 70.052 & 0.609 & 0.823 \\
\hline
\end{tabular}

Source: Questionnaire and SPSS 20 result. 
Table 12. Regression result of factors of production and the private investment.

\begin{tabular}{|c|c|c|c|c|c|c|}
\hline Predictor variable & B & S.E. & Wald & Df & Sig. & $\operatorname{Exp}(B)$ \\
\hline Labor (Yes) & 1.664 & 0.615 & 0.165 & 1 & 0.280 & 3.515 \\
\hline Land (No) & 2.076 & 0.635 & 25.678 & 1 & 0.000 & 17.971 \\
\hline Material (No) & 4.829 & 0.648 & 15.577 & 1 & 0.002 & 5.071 \\
\hline Constant & 1.967 & 0.621 & .834 & 1 & 0.230 & 4.051 \\
\hline
\end{tabular}

Source: Questionnaire and SPSS 20 result.

From Table 11, the Cox \& Snell R Square 0.609 and Nagelkerke R Square value 0.823 show the model as a whole explained 60.9\% (Cox \& Snell R Square) and 82.3\% (Nagelkerke R Square) of the variance competition perception (Dependent Variable).

From Table 12, the variables land and material have a significant effect on the growth of private investment. In the case of this, city investors had faced several problems related to getting suitable land and easy access to materials for their investment and this situation results in restraining more investors from joining the business and expanding the existing business which results in a few numbers of projects existing and low competition in the sector. According to Acemoglu (2009), Blanke et al. (2009), Kenzu (2012), and Mehabaw (2011), easy access to suitable land and raw materials has a positive significant impact. In other word, easy access of those materials and suitable land for investment encourages the growth of private investment while difficulties in their access restrain investors. Finally, the last variable that is labor has no significant effect on the growth of private investment. Following this result, the study rejects the null hypotheses that state materials and land are not a statistically significant determinant of private investment in Dire Dawa.

\section{CONCLUSIONS AND RECOMMENDATIONS}

The study was conducted using logistic regression model. Accordingly, the results of regression analysis show that among the 17 variables 9 of them were statistically significant. Age, education, marital status, personal saving, inflation, public investment, investment incentives, land and material are those variables which significantly determine the growth level of the private investment in the city.

Since investment performance or decision making process of private investors is affected by their age and education level, the existence of number of young/adult and lower level educated investors in the city had a negative impact on the growth of the sector. Meaning that those investors been found in the early working age, at the time of their age reaching the prime and mature working age might have lots of experience. In addition, if early working age investors have been found in the business, through time, the overall number of investors found in prime working and mature working age would increase resulting in an increase from low to high concentration of investment competition and growth. But, the absence of this early working age investors eliminates such opportunities. Similarly, an increase in academic qualification results in a positive effect on investment growth. In other word, investor's educational qualification affects the ability to choose between different investment types and overall it affects the investment decision. This is to mean that an increase in educational level of investors may lead to an increase of better decisions to be made. But the rivers were in the city. Though the sector remains at its lower level, the existence of number of married investors who are operating in the sector using the benefits of their marriage, have contributed to their survival in their business and positively affecting the sector at least not to be at zero level with such circumstances.

On the other hand, the absence of personal savings for startup and record of high inflation rate was negatively determining the growth of the sector in the city. Inflation causes decrease in real income of the consumer or population who has fixed income, where the consumption rate will gradually decrease. This may lead to a reduction in expenditure by consumer and encourage manufacturers to reduce the production by reducing the production capacity. In addition, the sharp increase in the price of raw materials has an adverse impact on the investor's project. Hence, the sharp inflation rate recorded in the city was negatively affecting the growth of private investment in the city. The increase in personal saving directly contributes to the new investment decision. As a more personal saving improvement recorded, the more the number of private investment project that will be created and this may directly contribute to the growth of the private investment and vice versa. But, in the city's context, the personal saving contribution to their business was insignificant. However, if the personal saving behavior of individuals improved, new investment decision would be made which may result in the improved number of private projects and the low concentration would have been changed to high.

Moreover, poor incentives given by the government, poor public investment, difficulties in getting suitable land for business and material for the investment were negatively affecting the growth of the sector in the city. This results in the low growth of the private investment in the city. The more the government expenditure on infrastructure and incentives given to investors, the more the private investment to be encouraged. The reverse was happening in the city. Similarly, investors had faced several problems related to getting suitable land and material for their investment and this situation results in less willingness to expand the existing business and restrain them from joining new business for potential investors. However, if more investment incentive was 
prepared by the city administration and investment office, more public investment was made, and easy access of suitable land and material for the investors was implemented a number of actual and potential investors might be encouraged to invest. Thus, the low concentration of the sector would have been changed to high.

Thus, based on these conclusions, the following recommendations are forwarded:

(1) The city administration should set policies which is integrated with the country's policy and create favorable environment that may initiate a number of young investors (early working age) and educated potential investors to join the business that results in the long run to experienced prime working age and matured investors. This may be achieved through organizing small and medium enterprises (SMEs) and encouraging those youngsters found in those enterprises, etc. Similarly, close follow up by the city administration and investment office on those projects that are owned by prime working age investors may help to boost those investors' confidence and results in a good performance of the operation.

(2) It is advisable that the city administration, investment office and other offices create awareness on married investors on how the shared responsibilities with their partners positively affect their investment activity. Through this awareness creation, investors may understand the benefit of marriage which results in improved performance than those of single individuals.

(3) The city administration together with the investment office and the private investors revisit the practical application of investment incentives given to encourage private investments and take corrective measures accordingly. Similarly, it is recommended if further reform programs are instituted in order to allow more participation among the potential private investors and to motivate actual investors to diversify their business.

(4) Undertake public investment in a way that could promote the private investment. Similarly, the city's investment office has to make strong linkage and collaboration with the infrastructural facilities provider such as Ethiopian electric power corporation, telecommunication, road construction authority and other respective stakeholders to speed up these infrastructural expansions in progress. In addition, since all investments involve risks, both the actual and potential investors must have to understand the situation and by being risk taker it is advisable they join the investment.

(5) Undertake inflation controlling mechanisms/maintain price stability and reduce the negative impact of inflation so as to encourage private investors to invest. In addition, the investors themselves are advised to set up controlling system that may help them to control their own activities and operations of other investors and suppliers of material.

(5) Governments' awareness creation about the benefits of personal saving for the growth of investment and improving interest rate given for saving that might contribute to the improvement of individuals saving. Similarly, enhancing the real per capita income of the people. Finally, banking sectors has to pursue saving mobilization from all aspects of the economic agents.

(6) Creating consistent and transparent access for land and material policies and requirements that is applied for all investors, by creating clear administration and good governance at all levels. In addition, as a business person, investors themselves should have to consider different alternatives of sourcing those materials.

(7) Last, but not least, the researchers recommended that future studies should be undertaken by adequately accommodating different variables in extensive way.

\section{REFERENCES}

1. Abbott A, Jones P (2011). Procyclical government spending: Patterns of pressure and prudence in the OECD. Economics Letters 111(3):230-232.

2. Abhijeet C, Dinesh S (2010). Investment management by individual investors: A behavioural approach. IUP Journal of Behavioural Finance 7:7-18.

3. Acemoglu D (2009). Introduction to modern economic growth, Princeton NJ: Princeton University Press. Available at: https://press.princeton.edu/titles/8764.html

4. Adugna H (2013). Determinants of private investment in Ethiopia. Journal of Economics and Sustainable Development 4(20):186-194.

5. Ahangari A, Saki A (2012). A study on the effect of macroeconomics instability index on private investment in Iran. Management Science Letters 2(6):1939-1946.

6. Alesina A, Campante FR, Tabellini G (2008). Why is fiscal policy often procyclical?. Journal of the European Economic Association 6(5):1006-1036.

7. Ang JB (2010). Determinants of private investment in Malaysia: what causes the postcrisis slumps?. Contemporary Economic Policy 28(3):378-391.

8. Antonakis N (2008). Investment behavior of firms: A critical evaluation of some important contributions', paper presented to the management conference in University of York, U.K. June 23.

9. Arpaia A, Turrini A (2008). Government Expenditure and Economic Growth in the EU: Long-Run Tendencies and Short-Term Adjustment. SSRN Working Paper Series 300.

10. Bader M, Malawi A (2010). The impact of interest rate on investment in Jordan: a cointegration analysis. 
Journal of King Abdulaziz University: Economics and Administration 105(3055):1-26.

11. Bakare S (2011). The determinants of private domestic investment in Nigeria. Far East Journal of Psychology and Business 4(2):23-56.

12. Batistar M (2015). An analysis of the determinants of private sector investment in Kenya, Master's Thesis, university of Namibia.

13. Benos N (2009).Fiscal policy and economic growth: empirical evidence from EU countries. University of Ioannina Aisen, Ari, and Francisco Jose Veiga. 2013. Available at: https://mpra.ub.uni- muenchen.de/19174/

14. Blanke J, Marilou U, Iarossi G, Ondiege P (2009). The Africa Competitiveness Report 2009. World Economic Forum Geneva, Switzerland. pp. 84-93. Available at: https://www.afdb.org/fileadmin/uploads/afdb/Documents/Publications/Africa\%20Competitiveness\%20Rep ort\%202009.pdf

15. Clark M (1917). Business acceleration and the law of demand: a technical factor in economic cycles. Journal of Political Economy 25(3):217-235.

16. Dehn J (2000). Private investment in developing countries: The effects of commodity shocks and uncertainty. University of Oxford, Institute of Economics and Statistics, Centre for the Study of African Economies. Available at: http://core.ac. uk/download/ pdf/ 6280504. pdf

17. Doppelhofer G, Miller RI(2004). Determinants of long-term growth: A Bayesian averaging of classical estimates (BACE) approach. American Economic Review 94(4):813-

18. Frimpong J, Marbuah G (2010). The determinants of private sector investment in Ghana: An ARDL approach European Journal of Social Sciences 15(2):250-261.

19. Geetha N, Ramesh M (2011). A study on people's preferences in Investment Behaviour. International Journal of Engineering and Management Research 1(6):285-306.

20. Ghosh S, Gregoriou A (2008). The composition of government spending and growth: is current or capital spending better?. Oxford Economic Papers 60(3):484-516.

21. Gilliam J, Grable E (2010). 'Risk-tolerance estimation bias: Do married women and men differ?' Journal of Consumer Education 8(27):84-98. Grable JE, Joo SH (2000). A cross-disciplinary examination of financial risk tolerance. Consumer Interests Annual 46:151-

22. Hall E, Jorgenson D (1969). Tax policy and investment behavior: Reply and further results. The American Economic Review 59(3):388-401.

23. Haroon M, Nasr M (2011). Role of private investment in economic development of Pakistan. International Review of Business Research Paper 7(1):420-439.

24. Heena T (2015). Risk tolerance dependent on what? Demographics or personality type: Findings from an empirical research Journal of Marketing and Consumer Research 2(6):81-107. Available at: http://www.iiste.org/Journals/index.php/JMCR/article/download/17770

25. Herrmann A (2007). People get emotional about their money: Performing masculinity in a financial discussion board. Journal of Computer-mediated Communication 12(2):499-522.

26. Jain D, Mandot N (2012). Impact of demographic factors on investment decision of investors in Rajasthan. Journal of Arts Science and Commerce 2(3):81-92.

27. Jamshidinavid B, Chavoshani M, Amiri S (2012). The impact of demographic and psychological characteristics on the investment prejudices in Tehran stock. European Journal of Business and Social Sciences 1(5):41-53.

28. Jongwanich J, Kohpaiboon A (2008). Private investment: Trends and determinants in Thailand. World Development 36(10):1709-1724.

29. Kabra G, Mishra K, Dash K (2010). Factors influencing investment decision of generations in India: An econometric study. Asian Journal of Management Research 1(1):194-204.

30. Kariuki DK (2003). Determinants of Fixed Capital Formation in Kenya. Unpublished MA Research Paper, Makerere University, Kampala, Uganda.

31. Kenzu Y (2012). Determinants of private investment: evidenced from Bahirdar City' Master's Thesis, University of Mekelle.

32. Keynes M (1936). The General Theory of Employment, Interest and Money, Macmillan, New York.

33. Knight J, Ding S (2009). Why does China invest so much?' Papers of Centre for the Study of African Economies (CSAE), Conference on Economic Development in Africa at St. Catherine‘s College, Oxford, UK.

34. Lamartina S, Zaghini A (2008). Increasing public expenditure: Wagner's law in OECD countries. German Economic Review 12(2):149-164.

35. Matwanga F (2007). Factors affecting private investment in Kenya, Msc. Desertation, university of Kampala, Uganda.

36. McKinnon R (1973). Money and Capital in Economic Development, The Brookings Institute, Washington D.C. 
37. Mehabaw T (2011). Assessment of opportunities and challenges for private investment, A case study of Kombolcha town', Masters Thesis, University of Addis Ababa.

38. Ndikumana L, Verick S (2007). The linkages between FDI and domestic investment: Unravelling the developmental impact of foreign investment (No. 2007-13). Working Paper, University of Massachusetts, Department of Economics. Available at: https://www.econstor.eu/handle/ 10419/64232

39. Ouattara B (2005). Modeling the long run determinants of private investment in Senegal (No. 04/05). Credit Research Paper. Available at: https://www.econstor.eu/bitstream/ 10419/81768/1/04-05.pdf

40. Raza S, Jahangir S, Zaigham H, Shafi S (2013). Investment preferences and risk level: Behavior of salaried individuals. IOSR Journal of Business and management 10(1):68-78.

41. Record R, Davies S (2007). Determinants and Impact of Private Sector Investment in Malawi: Evidence from the 2006 Investment Climate Survey', Papers of Centre for the Study of African Economies (CSAE), Conference on Economic Development in Africa at St. Catherine's College, Oxford, UK. Available at: https://mpra.ub.uni- muenchen.de/id/ eprint/3818

42. Sadiq MN, Ishaq HM (2014). The effect of demographic factors on the behavior of investors during the choice of investment: evidence from twin cities of Pakistan. Global Journal of Management and Business Research 14(3):98-102.

43. Sajid Y, Sarfraz M (2008). Savings and Economic Growth in Pakistan: An issue of causality. Pakistan Economic and Social Review 64:17- 36.

44. Seruvatu E, Jayaraman TK (2001). Determinants of private investment in Fiji. Economics Department, Reserve Bank of Fiji. Available at: http://www.rbf.gov.fj/docs/wp2001-02.pdf

45. Shaw S(1973). Financial Deepining Economic Development, Oxford University Press, UK.

46. Szarowská I (2012). The cyclicality of government expenditure and Wagner's law- Case of Czech Republic, Slovakia, Hungry, Bulgaria and Romania." Scientific Papers of the University of Pardubice. Series D, Faculty of Economics \& Administration vol.18, no.24.

47. Teklebrhan A, Sahlu T (2014). Determinants of domestic private investment firm growth in Ethiopia, a case study in Mekelle city, Tigray. International Journal of Research in Commerce and Management 5(6):16-28.

48. Tobin J (1969). Ageneral equilibrium approach to monetary theory. Journal of Money, Credit and Banking 1(1):15-29.

49. United Nations (2002), Report of the International Conference on Financing for Development, Monterrey.

50. Verma R (2009). Household, Private and Public Savings and Investment, Foreign Capital Inflows and GDP Growth in India with Structural Breaks 1950-2005', Singapore Economic Review Conference, World Scientific, Singapore, pp. 1-28. Available at: http://ro.uow.edu.au/commpapers/2080/

51. Wahid A, Salahuddin M, Noman A (2008). Saving investment correlation in South Asia-a panel approach. European Journal of Economics, Finance and Administrative Sciences 7(11):153-159.

52. World Bank (2004). A better investment climate for everyone, World Bank and Oxford University Press, Washington DC. Available http://siteresources.worldbank.org/ INTWDR 2005/ Resources/ complet e_report.pdf 